\title{
ZnO Nanoparticle Biosynthesis and Its Effect on Phosphorous-Mobilizing Enzyme Secretion and Gum Contents in Clusterbean (Cyamopsis tetragonoloba L.)
}

\author{
Ramesh Raliya $\cdot$ J. C. Tarafdar
}

Received: 29 September 2012/Accepted: 27 December 2012/Published online: 20 January 2013

(C) NAAS (National Academy of Agricultural Sciences) 2013

\begin{abstract}
Biological synthesis of $\mathrm{ZnO}$ nanoparticle is a new approach for environmentally benign protocol in context to green nanotechnology. In present investigation, $\mathrm{ZnO}$ nanoparticles were synthesized from $\mathrm{ZnNO}_{3}$ using extracellular secretions of Aspergillus fumigatus TFR-8 (NCBI GenBank Accession No. JQ675291) and effect of these biologically transformed $\mathrm{ZnO}$ nanoparticles was studied on clusterbean (Cyamopsis tetragonoloba L.) to enhance native phosphorousmobilizing enzymes and nanoinduced gum production. Valid characterization techniques were employed for confirmation of size, shape, surface structure, crystalline nature, and elemental proportion. Results indicate that synthesized nanoparticle size ranging between 1.2 and $6.8 \mathrm{~nm}$ at least in one dimension with oblate spherical and hexagonal in structure. The samples contained $98 \%$ atom of $\mathrm{Zn}$ element. The characterized $\mathrm{ZnO}$ nanoparticles were foliar sprayed at $10 \mathrm{ppm}$ concentration on leaf of 14-day-old clusterbean plants. A significant improvement in plant biomass (27.1\%), shoot length $(31.5 \%)$, root length $(66.3 \%)$, root area $(73.5 \%)$, chlorophyll content $(276.2 \%)$, total soluble leaf protein $(27.1 \%)$, rhizospheric microbial population (11-14\%), acid phosphatase $(73.5 \%)$, alkaline phosphatase (48.7\%), and phytase $(72.4 \%)$ activity in clusterbean rhizosphere was observed over control in 6-week-old plants due to application of nano$\mathrm{ZnO}$. The gum content in clusterbean seeds improved by $7.5 \%$ after maturity which indicates $\mathrm{ZnO}$ in nano form may contribute more in industrial and medical applications besides agricultural sector. A possible hypothesis of mechanism for $\mathrm{ZnO}$ nanoparticle biosynthesis has also been made.
\end{abstract}

Keywords Aspergillus fumigatus TFR-8 $\cdot$ Clusterbean $\cdot \mathrm{Gum} \cdot \mathrm{ZnO}$ Nanoparticle biosynthesis $\cdot$ P-mobilizing enzymes

\section{Introduction}

Potential applications of zinc nanomaterials include optoelectronics [19], nanolasers [12], solar cells [25], gas sensors [14], antibacterial [13, 16] personal care products, coating and paints [2, 40, 42], and health-related applications [43]. In biological systems, zinc plays significant roles in a wide variety of metabolic processes such as carbohydrate, lipid, nucleic acid, and protein synthesis as well as their degradation. In addition, zinc is an integral component of many enzyme structures and is the only

R. Raliya · J. C. Tarafdar $(\bowtie)$

Central Arid Zone Research Institute, Jodhpur 342003,

Rajasthan, India

e-mail: jctarafdar@yahoo.in; tarafdar@cazri.res.in metal to be represented in all six enzyme classes viz. oxidoreductases, transferases, hydrolases, lyases, isomerases, and ligases [3]. Zinc is one of the essential nutrients required for plant growth. Its important role can be adjudged as it controls the synthesis of indole acetic acid (IAA), a phytohormone which dramatically regulates the plant growth. It is also necessary for the chlorophyll synthesis and carbohydrate formation [38]. It enables the plants to withstand lower air temperatures and helps in the biosynthesis of cytochrome, a pigment that maintains the plasma membrane integrity and the synthesis of leaf cuticle. The improvement of $\mathrm{Zn}$ nutritional status also reduces the uptake of harmful heavy metals, i.e., hinders their toxicity in plants, such as $\mathrm{Cd}$ [1]. As $\mathrm{Zn}$ is the structural component of phosphorous (P)-mobilizing phosphatase and phytase enzymes, it can be hypothesized 
that application of nanoZnO may help in more secretion of $\mathrm{P}$-mobilizing enzymes, which is involved in native $\mathrm{P}$ mobilization for plant nutrition from unavailable organic sources [35].

$\mathrm{P}$ is required for plant growth and development [37]. In soil, total $\mathrm{P}$ is in adequate amount, but it mainly present in unavailable form of plants [26, 32]. Plants may increase $\mathrm{P}$ uptake from the soil by altering root morphology or physiology [6]. Physiological changes such as release of protons, organic acid anions or phenolics, P-mobilizing phytase, and phosphatase enzymes increase the availability of $\mathrm{P}$ in the rhizosphere [8]. Hence, release of phosphatase and phytase enzymes by roots and microorganisms that mineralize organic $\mathrm{P}$ can be an important mechanism for increasing $\mathrm{P}$ uptake by plants [36].

Experimental crop, Clusterbean (Cyamopsis tetragonoloba) was used in present investigation because it has diversified industrial applications, viz., paper, food, cosmetics, mining, petroleum, well drilling, pharmaceuticals, etc. [23, 28]. Clusterbean gum has emerged as the most important agro-chemical, which is non-toxic, eco-friendly, and generally recognized as safe (GRAS) by FDA. In addition, it uses as vegetable (fruit part), fodder (shoot and fruit), and green manure (whole plant). The crop is grown as a cash crop across the world [24].

There are several procedures for the synthesis of ultrafine metal oxide nanoparticles such as sol-gel [39, 44], aerosol [11], template-assisted [31], sonochemical [20], laser exposer [30], and thermal decomposition [21]. These methods often required several processing steps, controlled $\mathrm{pH}$, temperature, pressure, much expensive equipments, and toxic chemicals. In addition, these techniques also generate several by-products which are toxic to ecosystems. Therefore, a biological synthesis of $\mathrm{ZnO}$ nanoparticles has been attempted in this study. Microorganisms like fungi and bacteria having naturally bestowed property of reducing and oxidizing metal ions into metallic or metal oxide nanoparticles thereby functioning as nanofactories $[10,15,29]$. The present investigation embodies in biosynthesis of $\mathrm{ZnO}$ nanoparticle and its effect on P-mobilizing enzymes in rhizosphere and gum contents in clusterbean grains. Possible hypothetical mechanism for nanoparticle biosynthesis and translocation of $\mathrm{ZnO}$ nanoparticles in plants was made.

\section{Materials and Methods}

Physicochemical Characteristics of Soil Used for the Study

The experimental soil was collected from Central Research Farm of Central Arid Zone Research Institute $\left(26^{\circ} 18^{\prime} \mathrm{N}\right.$ $\left.73^{\circ} 01^{\prime} \mathrm{E}\right)$, Jodhpur. The climate of the region was arid with
Table 1 Characteristics of the experimental soil

\begin{tabular}{lc}
\hline Parameter & Quantity \\
\hline Sand (\%) & $85.1 \pm 2.2$ \\
Slit (\%) & $6.9 \pm 1.5$ \\
Clay (\%) & $7.5 \pm 1.0$ \\
pH & $8.1 \pm 0.1$ \\
EC $\left(\mathrm{dS} \mathrm{m}{ }^{-1}\right)$ & $0.3 \pm 0.05$ \\
Organic matter (\%) & $0.35 \pm 0.03$ \\
Total N $\left(\mathrm{mg} \mathrm{kg}^{-1}\right)$ & $462 \pm 18.5$ \\
Total P $\left(\mathrm{mg} \mathrm{kg}^{-1}\right)$ & $733 \pm 23.5$ \\
Total K $\left(\mathrm{mg} \mathrm{kg}^{-1}\right)$ & $695 \pm 21.9$ \\
\hline
\end{tabular}

a mean annual precipitation was $360 \mathrm{~mm}$ and the soil was loamy sand (hypothermic typic haplocambids). Characteristics of the soil are presented in Table 1. pH and EC (soil/ water ratio $1: 2.5$ ) of the soil sample were determined by a glass electrode conductivity bridge, respectively. Organic carbon (OC) was estimated by the method of Walkley and Black [41] using $1 \mathrm{~N}$ potassium dichromate and backtitrated with $0.5 \mathrm{~N}$ ferrous ammonium sulfate solution. $\mathrm{N}$, $\mathrm{P}$, and $\mathrm{K}$ in soil samples were estimated as described by Jackson [9].

\section{Isolation of Fungi}

The soil fungus, Aspergillus fumigatus TFR-8 (NCBI GenBank Accession No. JQ675291), was isolated from central agricultural research farm $\left(26^{\circ} 18^{\prime} \mathrm{N} 73^{\circ} 01^{\prime} \mathrm{E}\right)$ of Central Arid Zone Research Institute (CAZRI), Jodhpur, India. Isolation of fungi was carried out by plating the inoculum on Martin Rose Bengal Agar medium (Hi-Media, India, $\mathrm{pH}$ 7.2) after serial dilutions of pooled soil sample. Bacterial contamination was inhibited by supplementing the medium with chloramphenicol (Sigma-Aldrich, St. Louis, USA) at a concentration of $10 \mu \mathrm{g} \mathrm{mL}^{-1}$ after autoclaving. Inoculated plates were incubated at $28^{\circ} \mathrm{C}$ for $72 \mathrm{~h}$ in BOD incubator (Surana Scientific, India). Individual fungal colonies were picked and further purified by sub-culturing on Potato Dextrose Agar (PDA) media (Hi-Media, India). Preliminary identification of fungal isolates was performed on the basis of morphological characteristics.

\section{Molecular Characterization of Fungal Isolate}

The identification of the fungal isolate was carried out on the basis of morphological and microscopic observations such as color, structure of the mycelia, spore formation pattern, etc., which was followed by molecular level identification in which partial sequencing of $18 \mathrm{~S}$ and $28 \mathrm{~S}$ rRNA and complete sequence of internal transcribed 

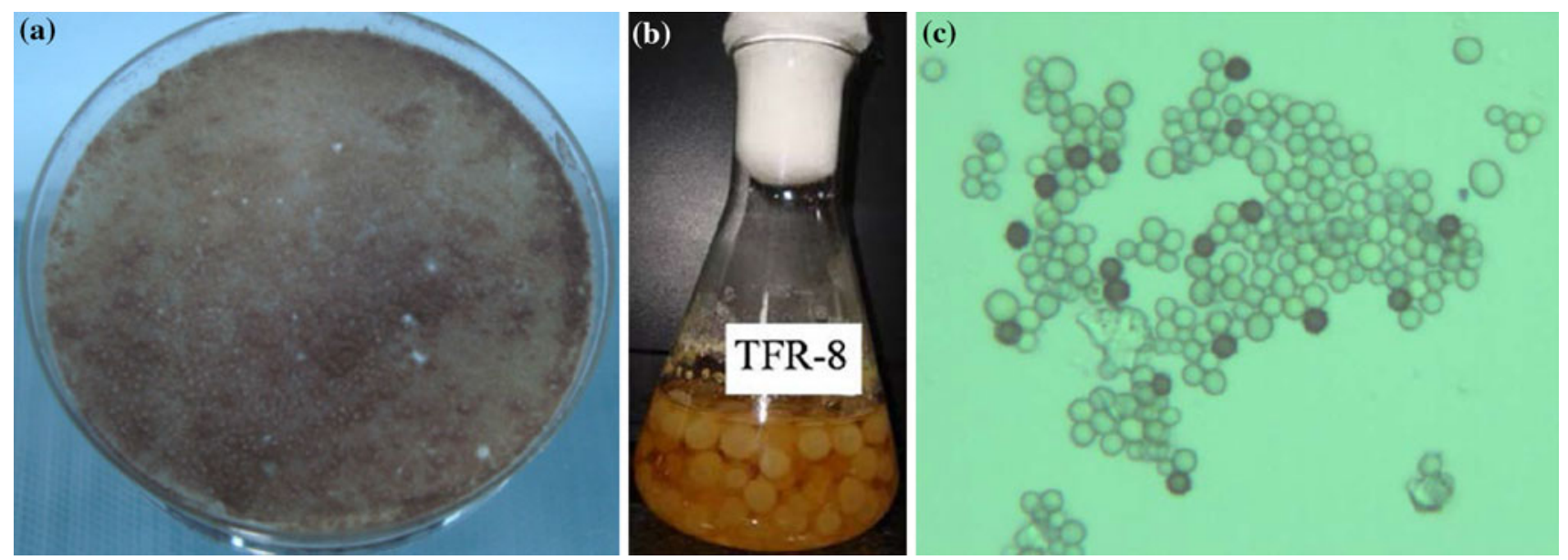

Fig. 1 a Isolated fungi Aspergillus fumigatus TFR-8 used for biosynthesis of $\mathrm{ZnO}$ nanoparticles. b Fungal ball of mycelia used for collection of extracellular fungal enzymes. c $A$. fumigatus TFR- 8 spore

sequence 1 (ITS1), internal transcribed sequence 2 (ITS2) and $5.8 \mathrm{~S} \mathrm{r}$ RNA gene (complex of $-18 \mathrm{~S}-\mathrm{ITS} 1-5.8 \mathrm{~S}-$ ITS2-28S-) was done using universal primer ITS1 $\left(5^{\prime}-\right.$ TCCGTAGGTGAACCTGCG-3') and ITS4 ( $5^{\prime}$-TCCTCCG CTTATTGATATGC- $3^{\prime}$ ). The genomic DNA was isolated by CTAB extraction method suggested by Sambrook et al. [27]. The rRNA sequence was submitted to GenBank of National Centre for Biotechnological Information (NCBI).

Biosynthesis of $\mathrm{ZnO}$ Nanoparticle

The fungi Aspergillus fumigatus TFR-8 (NCBI GenBank Accession No. JQ675291) was grown up in 250-mL Erlenmeyer flask containing 100-mL broth medium, composed of $0.3 \%$ malt extract, $1 \%$ sucrose, $0.3 \%$ yeast extract, and $0.5 \%$ peptone. After adjusting the $\mathrm{pH}$ of the medium to 5.8 , the culture was grown with continuous shaking on a rotary shaker $(150 \mathrm{rpm})$ at $28{ }^{\circ} \mathrm{C}$ for $72 \mathrm{~h}$. After complete incubation, fungal balls of mycelia (shown in Fig. 1b) were separated from the culture broth by filtration process using Whatman filter paper (Whatman, England) No. 1 under biosafety cabinet (iMSet, Surana Scientific, India) and then the fungal mycelia were washed thrice with sterile double-distilled water. The harvested fungal mycelia (10-g wet weight) was re-suspended in 100 -mL sterile Milli-Q-water in 250-mL Erlenmeyer flask and again put into a rotary shaker $(150 \mathrm{rpm})$ at $28{ }^{\circ} \mathrm{C}$ for $48 \mathrm{~h}$. After incubation, the cell-free filtrate was obtained by separating the fungal biomass using 0.45-microsize membrane filter (Whatman, England). Using cell-free filtrate, salt solution of zinc nitrate $\left(\mathrm{ZnNO}_{3}\right.$; Merck, Germany) was prepared with final concentration of $0.1 \mathrm{mM}$ in Erlenmeyer flasks, which was found to be optimum salt concentration for the synthesis of monodisperse $\mathrm{ZnO}$ nanoparticles in our preliminary experiment. The entire mixture was put into rotary shaker at $28{ }^{\circ} \mathrm{C}$ at $150 \mathrm{rpm}$. The reaction was allowed to carry out for a period of $72 \mathrm{~h}$. The biotransformed product was collected periodically for characterization of particle size.

Characterization of $\mathrm{ZnO}$ Nanoparticle

\section{Dynamic Light Scattering (DLS) Analysis}

The particle size distribution and zeta potential of $\mathrm{ZnO}$ nanoparticles were monitored using DLS measurements which determines particle size by measuring the rate of fluctuations in the laser light intensity scattered by particles as they diffuses through solvent. Particle size analyzer (Beckman DelsaNano C, USA) was used for size measurement and confirmation of nanoparticles size distribution.

\section{Transmission Electron Microscope and High-Resolution Transmission Electron Microscope Analysis}

For the confirmation of size and shape, transmission electron microscope (TEM) measurements was carried out using drop coating method in which a drop of solution containing nanoparticles was placed on the carbon-coated copper grids and kept under vacuum desiccation for overnight before loading them onto a specimen holder. TEM and high-resolution (HR)-TEM micrographs of the sample were taken using the JEM-2100F TEM instrument. The instrument was operated at an accelerating voltage of $200 \mathrm{kV}$.

\section{Scanning Electron Microscopy (SEM) Analysis}

SEM was extremely useful for the determination of topology and observations of surfaces as they offer better 
resolution and depth of field than optical microscope. Micrographs of the biologically synthesized samples were taken using the Hitchi-S-3400N SEM instrument. The instrument was operated at an accelerating voltage of $30 \mathrm{kV}$.

\section{Atomic Force Microscopy Analysis}

To study near-atomic-resolution with 3D surface topography, Veeco di CP-II scanning probe microscope in atomic force, tapping mode with closed loop $5 \times 5 \mu \mathrm{m}$ scanner was used.

\section{X-ray Diffraction (XRD) Analysis}

The crystal structure and size confirmation were examined by XRD analysis. XRD analyses of $\mathrm{ZnO}$ nanoparticle were carried out by thin film mode of XRD using X'PERT PRO MRD model of PANalytical system operated at $20 \mathrm{kV}$ voltages and a current of $15 \mathrm{~mA}$ with $\mathrm{Cu} \mathrm{K} \alpha$ radiations.

\section{Electron Dispersive X-Ray Spectroscopy (EDS) Analysis}

For EDS, samples were prepared on a carbon-coated copper grids and kept under vacuum desiccation for $3 \mathrm{~h}$ before loading them onto a specimen holder. Elemental analysis on single particles was carried out using Thermo-Noran EDS attachment equipped with TEM (JEM-2100F). It was performed for determination of the elemental composition and purity of the sample by atom $\%$.

\section{Effect of ZnO Nanoparticle on P-Mobilizing Enzyme} Secretion by Clusterbean (Cyamopsis tetragonoloba L.)

The seeds of clusterbean (Cyamopsis tetragonoloba L.) were obtained from seed house of CAZRI, India and sown at $3 \mathrm{~cm}$ depth, which, were thinned to three per pot after seedlings establishment. The pots were completely randomize and re-positioned weekly to minimize any effect of uneven environmental factors. The experiment was carried out in a green house with temperature between 25 and $35{ }^{\circ} \mathrm{C}$ (min-max) and $60 \%$ humidity. Pots, $30 \mathrm{~cm}$ height and $11 \mathrm{~cm}$ diameter, were used for this study. Surface soil $(0-20 \mathrm{~cm})$ was collected from fallow land of CAZRI Research farm. Any discernible root pieces were removed and the sample were air-dried for $48 \mathrm{~h}$ at $30{ }^{\circ} \mathrm{C}$, sieved $(<2 \mathrm{~mm})$ and thoroughly mixed. The mixed soil was filled to the pots $10 \mathrm{~kg}$ in each.

The experiment was carried out with three treatments, control (without $\mathrm{ZnO}$ application), ordinary size, and nano size $\mathrm{ZnO}$ and there were each of six replicates. No fertilizer was used in any of the treatment. The $\mathrm{ZnO}$ particles were sprayed by foliar (25-mL per pot) after 2 weeks of germination at a concentration of $10 \mathrm{mg} \mathrm{L}^{-1}$, which was found optimum in our preliminary experiment. Three pots in each treatment were harvested after 2 weeks of foliar spray (28-day-old plant). Shoots were cut at the soil surface and roots were carefully shaken to remove excess soil, and clumps of soil trapped between roots were taken out. The roots were transferred to a beaker, and cleaned by gentle shaking of the beaker after adding $0.2-\mathrm{mM} \mathrm{CaCl}_{2}$ solution. The roots were taken out of the soil extract and processed further for root length, area and diameter measurement using Delta T Scan Software (DELTA SCAN, England), for this roots were dipped in a solution of methylene blue dye for $6 \mathrm{~h}$ while shoot length was measured on meter scale. Representative soil samples were taken out (100 g) from the bulk soil of the pots in which plants were grown, as well as from absolute control pot in which no plants were grown and frozen at $4{ }^{\circ} \mathrm{C}$ for further analysis.

Biochemical parameters including dehydrogenase, acid, and alkaline phosphatase was estimated according to Tabatabai [33] and Tabatabai and Bremner [34]. Phytase, plant P [9], total chlorophyll content [17], total soluble leaf protein content [18] were also assayed. After biochemical analysis, rhizospheric microbial populations were counted. The gum viscosity and the gum contents were measured as described by Yoko [45].

\section{Results and Discussion}

Physicochemical Characteristics of Rhizosphere Soil

The characteristic of the experimental soils studied is presented in Table 1. The soil is alkaline in reaction with low EC, organic matter, and $\mathrm{N}$ content.

Isolation and Identification of the Fungus

Identification of the fungus (Aspergillus fumigatus TFR-8) was made on the basis of morphological parameter including spore formation, hyphal colonization, and color after staining with cotton blue dye (Fig. 1a-c), and molecular characterization of fungal isolate was performed by partial sequencing of $18 \mathrm{~S}$ and $28 \mathrm{~S}$ rRNA and complete sequence of internal transcribed sequence 1 (ITS1), internal transcribed sequence 2 (ITS2) and 5.8S rRNA gene (complex of -18S-ITS1-5.8S-ITS2-28S-), which has been submitted in NCBI GenBank (Accession No. JQ675291). The sequence was compared using Basic Local Alignment Search Tool (BLAST) of NCBI and submitted sequence is available on a public domain http://www.ncbi.nlm.nih.gov. 
Extracellular Biosynthesis of Zinc Oxide Nanoparticles

The extracellular synthesis of $\mathrm{ZnO}$ nanoparticles was carried out by exposure of a precursor salt zinc nitrate $\left(\mathrm{ZnNO}_{3}\right)$ solution of $0.1 \mathrm{mM}$ concentration to fungal cellfree filtrate obtained by incubating the fungus Aspergillus fumigatus TFR- 8 in an aqueous solution. The reaction was carried out for $72 \mathrm{~h}$.

\section{Characterization of $\mathrm{ZnO}$ Nanoparticles}

Particle size of biotransformed $\mathrm{ZnO}$ nanoparticles was analyzed by DLS using particle size analyzer (Fig. 2). Histogram shows particle size ranges from 1.2 to $6.8 \mathrm{~nm}$ and possess an average size of $3.8 \mathrm{~nm}$. The Polydispersity index (PDI) was 0.335 shows high monodispersity of the particle. The size was further confirmed by TEM, SEM, and AFM analyses.

TEM measurements were used to determine the size, shape, and morphological study of $\mathrm{ZnO}$ nanoparticles. A TEM micrograph (Fig. 3a) showed well distribution of spherical $\mathrm{ZnO}$ nanoparticle, which was encapsulated by thin layer of protein at the measurement scale bar of $100 \mathrm{~nm}$ with $200 \mathrm{kV}$ applied voltage. The nanoparticles were oblate spherical with clear edge of crystal and lattice structure observed in HR-TEM micrograph (Fig. 3b), which supports the crystalline nature of $\mathrm{ZnO}$ nanoparticle.

SEM micrograph revealed the structural and topology of $\mathrm{ZnO}$ nanoparticles (Fig. 4). Nanoparticles were of oblate spherical and hexagonal in structure which was uniformly distributed (monodispersed) without any significant agglomeration.

Figure 5a and $\mathrm{b}$ shows the 3D micrograph of a single $\mathrm{ZnO}$ nanoparticle and histogram, respectively, which confirms the TEM and SEM results. AFM histogram shows the average height of particle is $8.56 \mathrm{~nm}$.

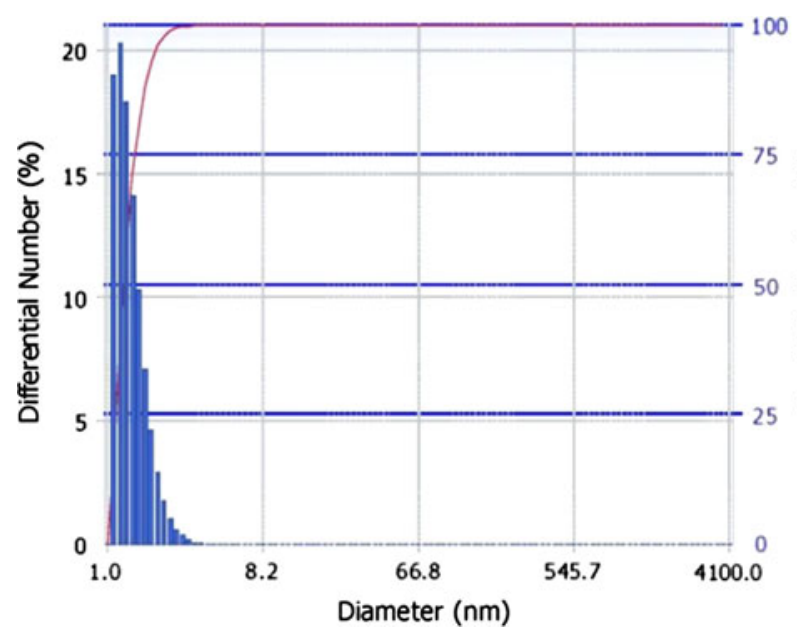

Fig. 2 DLS histogram of magnesium nanoparticles for particle size analysis
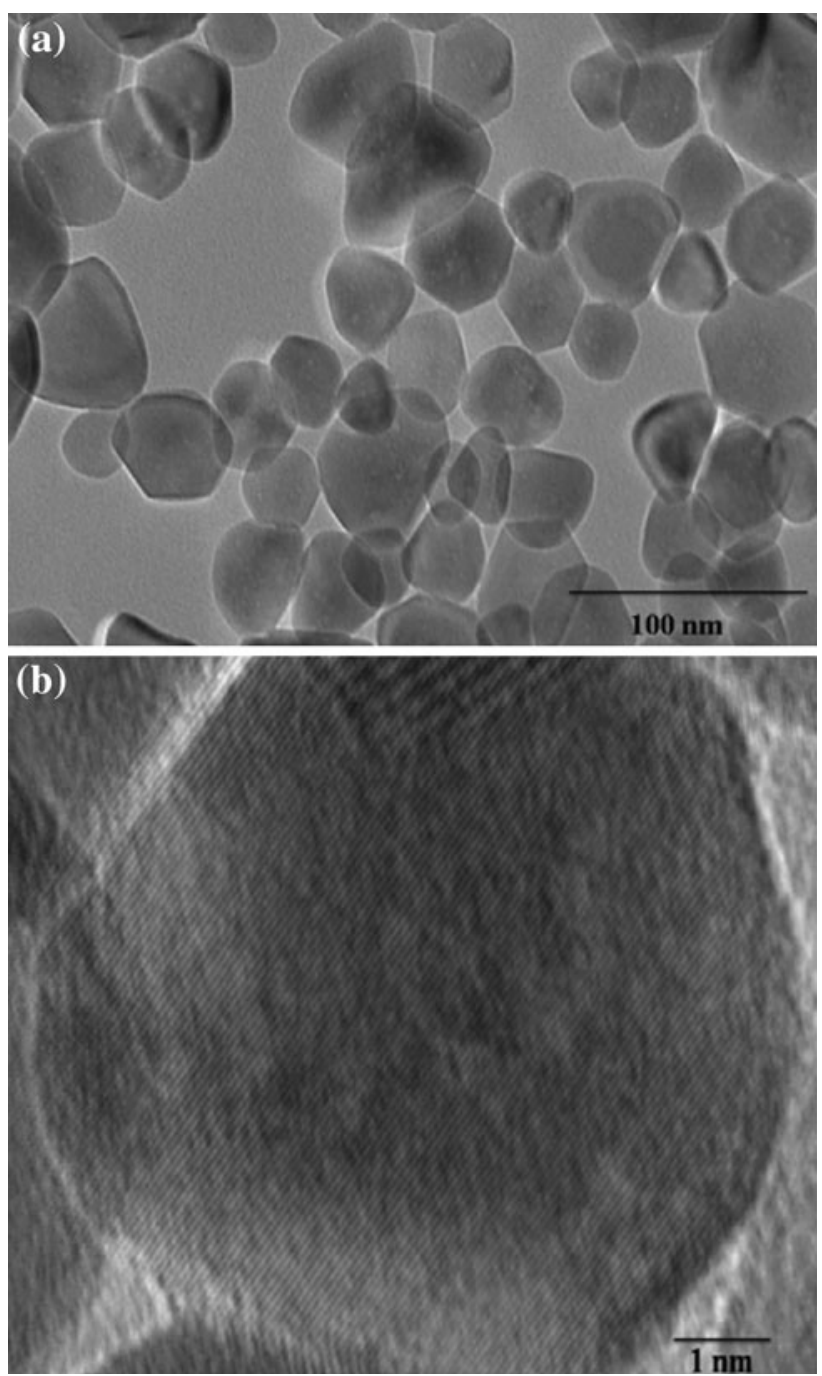

Fig. 3 a TEM micrograph of biologically synthesized $\mathrm{ZnO}$ nanoparticle. b HR-TEM micrograph of single $\mathrm{ZnO}$ particle

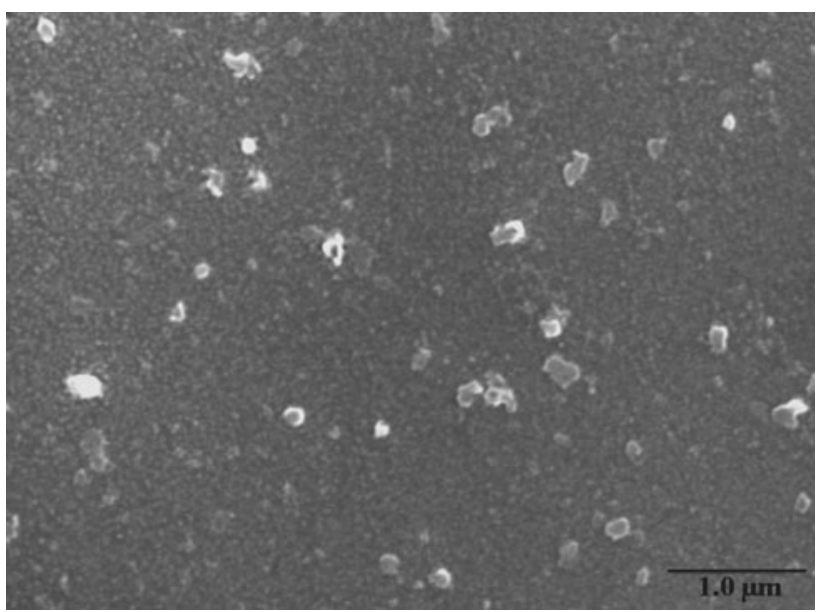

Fig. 4 SEM micrograph of monodisperse $\mathrm{ZnO}$ nanoparticle 

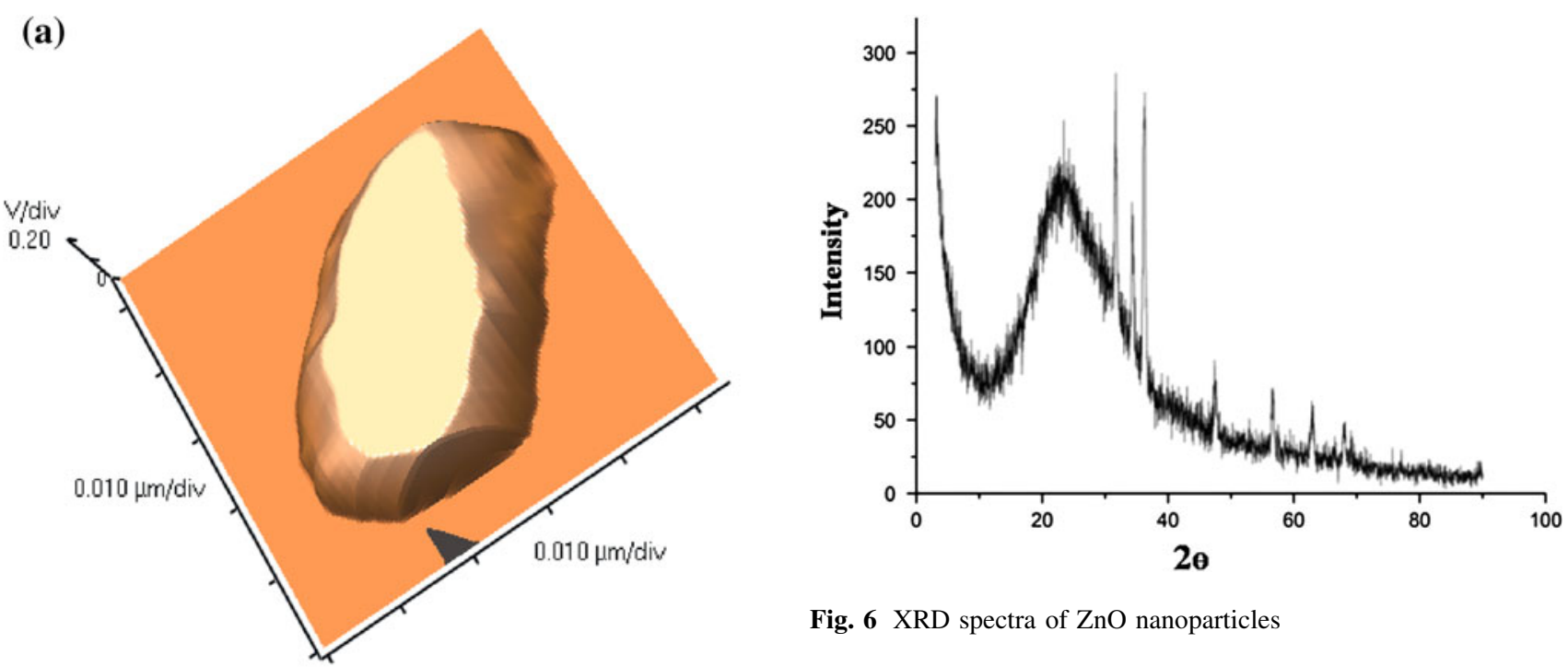

(b)

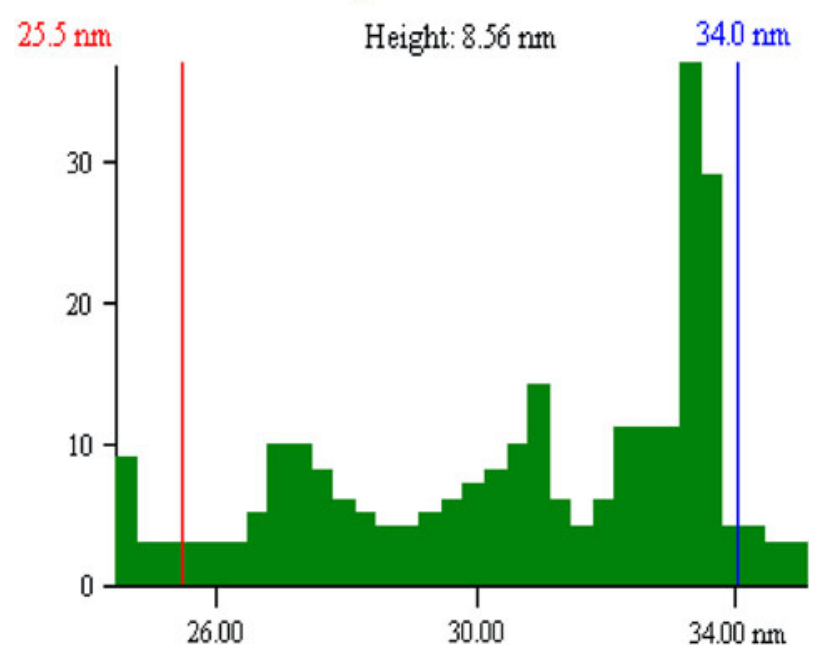

Fig. 5 a AFM image of single $\mathrm{ZnO}$ nanoparticle. b AFM histogram of $\mathrm{ZnO}$ nanoparticles

Figure 6 shows the XRD pattern of $\mathrm{ZnO}$ nanoparticles. Analysis of XRD spectra showed well-defined peaks at $2 \theta$ values, which correspond to hexagonal phase of $\mathrm{ZnO}$.

The EDS spectrum (full-scan mode) of drop coated $\mathrm{ZnO}$ nanoparticle shown in Fig. 7 confirms the purity of $\mathrm{ZnO}$ nanoparticles. The spectrum shows strong peak intensity of Zn (98 at.\%). Oxygen peaks were found, which confirms the metal in its oxide form.

\section{Stability of $\mathrm{ZnO}$ Nanoparticles}

The stability of $\mathrm{ZnO}$ nanoparticles was tested regularly till 125 days, using particle size analyzer by measuring hydrodynamic diameter of nanoparticles. The results showed (Table 2) nanosized particle $(>100 \mathrm{~nm})$ in entire solution
Fig. 6 XRD spectra of $\mathrm{ZnO}$ nanoparticles

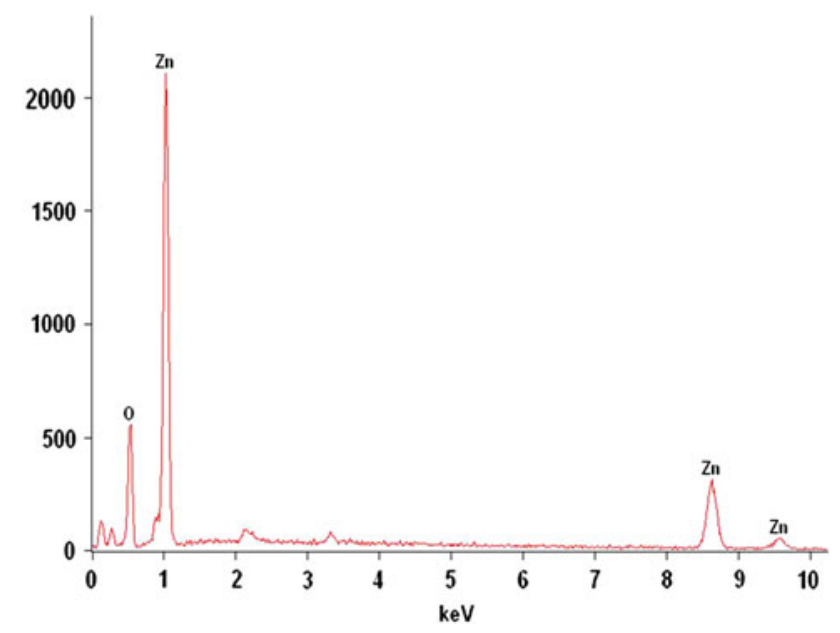

Fig. 7 EDX spectrum of biologically synthesized $\mathrm{ZnO}$ nanoparticle

was present till 90 days, thereafter, the average particle size exceeds $100 \mathrm{~nm}$ due to agglomeration. It may be concluded from the result that $\mathrm{ZnO}$ nanoparticles were stable till 90 days.

\section{Effect of ZnO Nanoparticles on Clusterbean}

The results demonstrated a significantly higher plant growth (Fig. 8) and dry biomass (Table 3) due to nanoZnO particles at 6 weeks of crop age. In general, $27.1 \%$ more plant biomass and significant improvement in shoot (31.51\%), root length (66.29 \%), and root area (73.52\%) due to foliar application of $\mathrm{ZnO}$ nanoparticles was noticed over control.

Photosynthetic pigment chlorophyll, total soluble leaf protein, and plant $\mathrm{P}$ concentration were increased by 276.2 , 27.1 , and $10.8 \%$, respectively, by application of $\mathrm{ZnO}$ nanoparticle at $10 \mathrm{mg} \mathrm{L}^{-1}$ concentration (Table 4). The results clearly indicate that biosynthesized nanoZnO particles were 


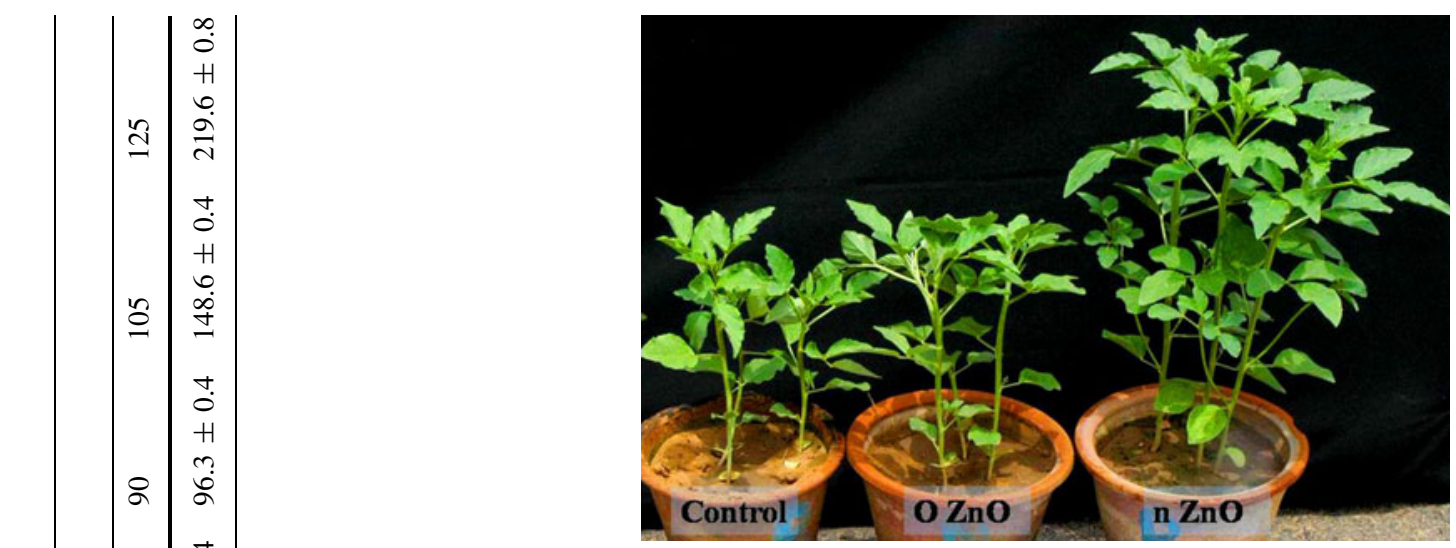

Fig. 8 Phenotype of clusterbean plant (4 weeks old) under varying treatment, $O \mathrm{ZnO}$-ordinary zinc oxide, $n \mathrm{ZnO}$-nano zinc oxide

Table 3 Phenological parameter of clusterbean plant at 6 weeks of crop age

\begin{tabular}{lcrrr}
\hline Treatment & $\begin{array}{l}\text { Shoot length } \\
(\mathrm{cm})\end{array}$ & $\begin{array}{l}\text { Root length } \\
(\mathrm{mm})\end{array}$ & $\begin{array}{l}\text { Root area } \\
\left(\mathrm{mm}^{2}\right)\end{array}$ & $\begin{array}{l}\text { Dry biomass } \\
\left(\mathrm{g}^{-1}\right)\end{array}$ \\
\hline Control & 44.53 & 720.23 & 809.30 & 10.47 \\
Ordinary ZnO & 47.73 & 835.20 & 1241.47 & 11.60 \\
Nano ZnO & 58.57 & 1197.70 & 1404.30 & 25.33 \\
LSD $(p=0.05)$ & 0.10 & 0.09 & 0.03 & 0.15 \\
\hline
\end{tabular}

Table 4 Total soluble protein, chlorophyll content, and $\mathrm{P}$ concentration in clusterbean plant at 6 weeks of crop age

\begin{tabular}{llcr}
\hline Treatment & $\begin{array}{l}\text { Total soluble } \\
\text { protein }\left(\mathrm{mg} \mathrm{kg}^{-1}\right)\end{array}$ & $\begin{array}{l}\text { Chlorophyll } \\
\text { content }\left(\mathrm{mg} \mathrm{kg}^{-1}\right)\end{array}$ & $\begin{array}{r}\mathrm{P} \text { uptake } \\
\left(\mathrm{mg} \mathrm{kg}^{-1}\right)\end{array}$ \\
\hline Control & 48.05 & 3.37 & 923.19 \\
Ordinary ZnO & 52.13 & 8.20 & 993.50 \\
Nano ZnO & 61.08 & 12.67 & 1023.27 \\
LSD $(p=0.05)$ & 0.02 & 0.07 & 0.50 \\
\hline
\end{tabular}

Table 5 Microbial population in rhizosphere of 6-week-old clusterbean plant

\begin{tabular}{llll}
\hline Treatment & $\begin{array}{l}\text { Fungi } \\
\left(\mathrm{CFU} \times 10^{-4}\right)\end{array}$ & $\begin{array}{l}\text { Bactria } \\
\left(\mathrm{CFU} \times 10^{-6}\right)\end{array}$ & $\begin{array}{l}\text { Actinomycetes } \\
\left(\mathrm{CFU} \times 10^{-5}\right)\end{array}$ \\
\hline Control & 21.63 & 41.67 & 18.44 \\
Ordinary ZnO & 23.33 & 42.33 & 21.34 \\
Nano ZnO & 24.67 & 47.33 & 24.15 \\
LSD $(p=0.05)$ & 1.13 & 1.33 & 1.04 \\
\hline
\end{tabular}

very effective for P mobilization, chlorophyll content, and soluble proteins in leaf. Results presented (Table 5) exhibited that rhizospheric microbial population was found to be increased between 11.8 and $13.8 \%$ by application of $\mathrm{ZnO}$ 
Table 6 P-mobilizing enzymes activity in rhizosphere of 6-week-old clusterbean plant

\begin{tabular}{llll}
\hline Treatment & $\begin{array}{l}\text { Acid phosphatase } \\
\left(\mathrm{EU} \times 10^{-4}\right)\end{array}$ & $\begin{array}{l}\text { Alkaline } \\
\text { phosphatase } \\
\left(\mathrm{EU} \times 10^{-4}\right)\end{array}$ & $\begin{array}{l}\text { Phytase } \\
\left(\mathrm{EU} \times 10^{-2}\right)\end{array}$ \\
\hline Control & 2.77 & 6.23 & 1.93 \\
$\begin{array}{l}\text { Ordinary } \\
\text { ZnO }\end{array}$ & 3.47 & 7.13 & 2.00 \\
Nano ZnO & 4.80 & & \\
$\begin{array}{c}\text { LSD } \\
(p=0.05)\end{array}$ & 0.08 & 9.27 & 3.33 \\
& & 0.05 & 0.10
\end{tabular}

Table 7 Gum content and viscosity in guar gum of clusterbean seeds at crop maturity

\begin{tabular}{lll}
\hline Treatment & Gum content $(\%)$ & Gum viscosity $(\mathrm{mPa})$ \\
\hline Control & 28.86 & 3030 \\
Ordinary ZnO & 30.93 & 3050 \\
Nano ZnO & 31.03 & 3126 \\
LSD $(p=0.05)$ & 1.5 & 4.8 \\
\hline
\end{tabular}

nanoparticles during critical growth stage (6 weeks) of crop. Table 6 indicates increased activity of phytase, acid, and alkaline phosphatase in the rhizosphere due to nanoZnO sprayed on clusterbean plants than ordinary size and control. It was also seen that gum content and its viscosity in clusterbean seed of $\mathrm{ZnO}$ nanoparticle sprayed plants were higher than ordinary size $\mathrm{ZnO}$ particles and control (Table 7).
In the biosynthesis of metal nanoparticle by a fungus, extracellular secreting enzymes are produced which reduce the metal salt of macro- or microscale into nanoscale diameter through catalytic effect. Negative electrokinetic potential of microorganisms make them to attract the cations and act as trigger of the procedure for biosynthesis of metal and metal oxide nanoparticles. Such a possibility of biosorption and bioreduction had been reported by Fu et al. [7]. Extracellular secretion of enzymes offers the advantage to obtain pure, monodisperse nanoparticles, which are free from cellular components, associated with organisms and easy downstream processing. Results clearly indicate the fungus Aspergillus fumigatus TFR-8 is capable to synthesize $\mathrm{ZnO}$ nanoparticle with the average diameter of $3.8 \mathrm{~nm}$ at least at one dimension. Such biologically synthesized, functional nanoparticles are economically cheap, easy downstream processing, and environmentally safe, because they are naturally encapsulated by fungal protein which act as capping agent. Our results of $\mathrm{ZnO}$ biosynthesis are supported by Jain et al. [10]; they described the biomimetic approach for $\mathrm{ZnO}$ synthesis. Such a biologically engineered $\mathrm{ZnO}$ can be directly used in biomedical, engineering, agricultural, and allied sectors. Results show the shoot-root growth, chlorophyll (photosynthetic pigment) content, total soluble leaf protein, rhizospheric microbial population, and $\mathrm{P}$ nutrient-mobilizing enzyme (phytase, acid, and alkaline phosphatase), which was significantly increased. The better response of $\mathrm{ZnO}$ nanoparticle might be due to its essentiality and act as cofactor for phytase and
Fig. 9 Hypothetical mechanism for biosynthesis of $\mathrm{ZnO}$ nanoparticles

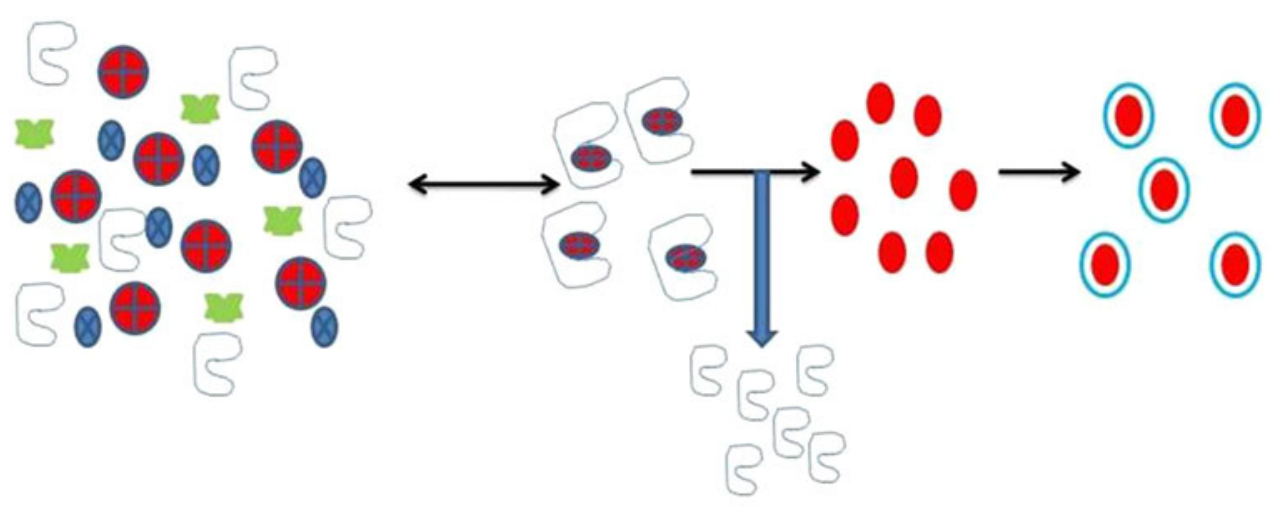

Fungal extracellular enzyme

Zinc ion

Nitrate ion

Water molecule

ZnO nanoparticle

Protein encapsulated ZnO nanoparticle 
phosphatase enzymes. The better growth of plants in response to nanoZnO is supported by Pandey et al. [22]. On the basis of experimental results, a schematic demonstration of the possible mechanism for biosynthesis of $\mathrm{ZnO}$ nanoparticles (Fig. 9) was presented. Nanoparticles are adsorbed to plant surface and taken up through natural nano- or micrometer scale plant openings. Several pathways exist which are predicted for nanoparticle association and uptake in plants [5]. Uptake rate depends on the size and the surface properties of nanoparticles. Results of nanoparticle penetration and transportation are also supported by Corredor et al. [4], by showing the penetration of nanoparticle in pumpkin plants. The biosynthesis mechanism for $\mathrm{ZnO}$ nanoparticle involves an enzyme-mediated process. The protein present in extracellular secrets, mentioned as capping protein, further encapsulates the $\mathrm{ZnO}$ nanoparticle and increases its stability. Penetration of nanoparticle might be through stomata of plant leaves. Nanoparticles were adsorbed to clusterbean leaves after spray and taken up through natural nano- or micrometer scale leaf openings. The uptake rate depends on the size and the surface properties of the nanoparticles. Nanoparticles could enter the xylem via the cortex and the central cylinder and may accumulate in the vacuole.

The present invention of nanoparticle biosynthesis is a low-cost green, ecofriendly approach, capable to producing monodisperse $\mathrm{ZnO}$ nanoparticles using the fungus Aspergillus fumigatus TFR-8. These biologically synthesized nanoparticles were found suitable for plant nutrition more particularly to clusterbean (Cyamopsis tetragonoloba). Results clearly demonstrate the greater improvement in shoot-root growth, chlorophyll (photosynthetic pigment), total soluble leaf protein content, rhizospheric microbial population, and $\mathrm{P}$ nutrient-mobilizing enzymes (phytase, acid and alkaline phosphatase) by the application of biologically synthesized $\mathrm{ZnO}$ nanoparticle at $10 \mathrm{mg} \mathrm{L}^{-1}$ concentration on 2-week-old plants. The gum content and its viscosity in seeds of clusterbean at crop harvest were also significantly improved by application of nanoZnO. However, invention opens new door for fertilizer industries to produce "Bionanofertilizer" for plant nutrition. The industries can bank upon this product to formulate $\mathrm{ZnO}$ bionanofertilizer in very near future.

\begin{abstract}
Acknowledgments Authors are appreciating World Bank-Indian Council of Agricultural Research (ICAR), National Agricultural Innovation Project (NAIP/C4/C-2032) for financial assistance. Authors are thankful to Advance Instrumentation Facility Centre (AIRF), Jawaharlal Nehru University, Delhi and Electron Microscopy and Nanoscience Laboratory, Panjab Agriculture University, Ludhiana for providing electron and atomic force microscopy facilities.
\end{abstract}

Conflict of interest The authors declare that they have no conflicts of interest.

\section{References}

1. Adiloglu A (2002) The effect of zinc (Zn) application on uptake of cadmium $(\mathrm{Cd})$ in some cereal species. Arch Agron Soil Sci 48:553-556

2. Akhtar MS, Ameen S, Ansari SA, Yang O (2011) Synthesis and characterization of $\mathrm{ZnO}$ nanorods and balls nanomaterials for dye sensitized solar cells. J Nanoeng Nanomanuf 1:71-76

3. Auld DS (2001) Zinc coordination sphere in biochemical zinc sites. Biometals 14:271-313

4. Corredor E, Testillano PS, Coronado MJ, Gonzalez PM, Rodrigo FP, Marquina C, Ibarra MR, Fuente JM, Rubiales D, Alejandro PL, Risueno MC (2009) Nanoparticle penetration and transport in living pumpkin plants: in situ subcellular identification, BMC Plant Biology. doi: 10.1186/1471-2229-9-45

5. Dietz KJ, Hearth S (2011) Plant nanotoxicity. Trends Plant Sci 16:582-589

6. Foehse D, Claassen N, Jungk A (1988) Phosphorous efficiency in plants: external and internal $\mathrm{P}$ requirement and $\mathrm{P}$ uptake efficiency of different plant species. Plant Soil 110:101-109

7. Fu JK, Liu YY, Gu PY, Tang DL, Lin ZY, Yao BX, Wen SZ (2000) Spectroscopic characterization on the biosorption and bioreduction of $\operatorname{Ag}(\mathrm{I})$ by Lactobacillus sp A09. Acta Phys Chim Sin 16:779-782

8. Gerke J (1993) Kinetics of soil phosphate desorption as affected by citric acid. Zeitschrift Fuer P Flanzenernaehrung Bodenkunde 157:17-22

9. Jackson ML (1967) Soil chemical analysis. Prentice-Hall of India, Delhi 498

10. Jain N, Bhargava A, Tarafdar JC, Singh SK, Panwar J (2012) A biomimetic approach towards synthesis of zinc oxide nanoparticles. Appl Microbiol Biotechnol. doi:10.1007/s00253-012-3934-2

11. Jiang J, Chen DR, Biswas P (2007) Synthesis of nanoparticles in a flame aerosol reactor with independent and strict control of their size, crystal phase and morphology. Nanotechnology. doi: 10.1088/0957-4484/18/28/285603

12. Johnson JC, Yan H, Schaller RD, Haber LH, Saykally RJ, Yang P (2001) Single nanowire lasers. J Phys Chem 105:11387-11390

13. Jones N, Ray B, Ranjit KT, Manna AC (2008) Antibacterial activity of $\mathrm{ZnO}$ nanoparticle suspensions on a broad spectrum of microorganisms. FEMS Microbiol Lett 279:71-76

14. Lee DD, Lee DS, Pook K (2001) Environmental gas sensors. IEEE Sens J 1:214-224

15. Lengke FM, Fleet EM, Southam G (2007) Biosynthesis of silver nanoparticles by filamentous cyanobacteria from a silver (I) nitrate complex. Langmuir 23:2694-2699

16. Li Q, Chen SL, Jiang WC (2007) Durability of nano ZnO antibacterial cotton fabric to sweat. J Appl Polym Sci 103:412-416

17. Lichtenthaler HK (1987) Chlorophylls and carotenoids: pigments of photosynthetic biomembranes. Methods Enzymol 148:350-382

18. Lowry OH, Rosebrough NJ, Farr AL, Randall RJ (1951) Protein measurement with the folin phenol reagent. J Biol Chem 193: 265-275

19. Mann S, Shenton W, Li M, Connolly S, Fitzmaurice D (2000) Biologically programmed nanoparticle assembly. Adv Mater 12: 147-150

20. Manoiv VS, Aloman A (2010) Obtaining silver nanoparticles by sonochemical methods. UPB Sci Bull B 72:179-186

21. Moghaddam AB, Nazari T, Badraghi J, Kazemzad M (2009) Synthesis of $\mathrm{ZnO}$ nanoparticles and electrodeposition of polypyrrole/ZnO nanocomposite film. Int J Electrochem Sci 4:247-257

22. Pandey AC, Sanjay SS, Yadav RS (2010) Application of ZnO nanoparticles in influencing the growth rate of Cicer arietinum. J Exp Nanosci 6:488-497 
23. Pathak R, Singh M, Henry A (2009) Genetic divergence in cluster bean (Cyamopsis tetragonoloba) for seed yield and gum content under rainfed conditions. Indian J Agric Sci 79:559-561

24. Pathak R, Singh SK, Singh M, Henry A (2010) Molecular assessment of genetic diversity in cluster bean (Cyamopsis tetragonoloba) genotypes. J Genet 89:243-246

25. Rensmo H, Keis K, Lindstrom H, Sodergren S, Solbrand A, Hagfeldt A, Lindquist SE (1997) High light-to-energy conversion efficiencies for solar cells based on nanostructured $\mathrm{ZnO}$ electrodes. J Phys Chem B 110:2598-2601

26. Richardson AE (2001) Prospectus for using soil microorganisms to improve the acquisition of phosphorous by plants. Aust J Plant Physiol 28:291-295

27. Sambrook J, Fritsch EF, Maniatis T (1989) Molecular cloning: a laboratory manual. Cold Spring Harbour Laboratory Press, New York

28. Senapati MK, Srinatha A, Pandit JK (2006) In vitro release characteristics of matrix tablets: study of karya gum and guar gum as release modulators. Indian J Pharm Sci 68:824-826

29. Shankar SS, Ahmad A, Pasrichaa R, Sastry M (2003) Bioreduction of chloroaurate ions by geranium leaves and its endophytic fungus yields gold nanoparticles of different shapes. J Mater Chem 13:1822-1826

30. Singhn SC, Gopal R (2007) Zinc nanoparticles in solution by laser ablation technique. Bull Mater Sci 3:291-293

31. Sreeram KJ, Nidhin M, Nair BU (2008) Microwave assisted template synthesis of silver nanoparticles. Bull Mater Sci 7: 937-942

32. Stevenson FJ, Cole MA (1999) Cycles of soils: carbon, nitrogen, phosphorous, sulfur, Micronutrients. Wiley, New York

33. Tabatabai MA (1982) Soil enzymes. In: Page AL, Miller RH, Keeney DR (eds) Methods of soil analysis, part 2. American Society of Agronomy, Madison, pp 903-947
34. Tabatabai MA, Bremner JM (1969) Use of p-nitrophenol phosphate for assay of soil phosphatase activity. Soil Biol Biochem $1: 301-307$

35. Tarafdar JC, Claassen N (2003) Organic phosphorus utilization by wheat plants under sterilized condition. Biol Fert Soils 39:25-29

36. Tarafdar JC, Yadav RS (2011) Hydrolysis of P fractions by phosphate and phytase producing fungi. Agrochimica 55:1-13

37. Vance CP (2011) Phosphorous as a critical macronutrient. In: Malcolm J, Hawkesford MJ, Barraclough P (eds) The molecular and physiological basis of nutrient use efficiency inn crops. Wiley-Blackwell, Chichester, pp 229-264

38. Vitosh ML, Warncke DD, Lucas RE (1994) Secondary and micronutrients for vegetable and field crops. Ichigan State Univ Ext Bull, pp E-486

39. Wahab R, Ansari SG, Dar MA, Kim YS, Shin HS (2007) Synthesis of magnesium oxide nanoparticle by sol-gel process. Mater Sci Forum 558:983-986

40. Wahab R, Kim YS, Lee DS, Seo JM, Shin HS (2010) Controlled synthesis of zinc oxide nanoneedles and their transformation to microflowers. Sci Adv Mater 2:35-42

41. Walkley A, Black IA (1934) An examination of the Degtjareff method for determining soil organic matter and a proposed modification of the chromic acid titration method. Soil Sci 37:29-38

42. Wang ZL (2004) Nanostructures of zinc oxide. Mater Today 7:26-33

43. Xu T, Xie CS (2003) Tetrapod-like nano-particle ZnO/acrylic resin composite and its multi-function property. Prog Org Coat 46:297-301

44. Yang H, Zhang K, Shi R, Li X, Dong X, Yu Y (2006) Sol-gel synthesis of $\mathrm{TiO}_{2}$ nanoparticles and photocatalytic degradation of methyl orange in aqueous $\mathrm{TiO}_{2}$ suspensions. J Alloy Compd 413:302-306

45. Yoko K (2008) Guar Gum, Chemical Technical Assessment (CTA) $\mathrm{PhD}$ Thesis 69th JECFA 